\title{
MARGARET ATWOOD'S HAG-SEED: DRAMATIC ENCOUNTERS BETWEEN CLASSIC AND ADAPTATION, LIFE AND ART, FREEDOM AND IMPRISONMENT
}

\begin{abstract}
A bstract. This paper examines Margaret Atwood's novel Hag-Seed (2016) as a metatextual adaptation of Shakespeare's literary classic The Tempest. The terms "adaptation" and "classic" are employed to explain the relation of Atwood's work to its source material. The performance of The Tempest prepared by the characters of the novel that engages convicts is a form of multi-media interactive theater, and the classical text of the Shakespearean play is considered a form of "sacra" (Turner), which has educational and utilitarian purposes. Michel Foucault's analysis of prison, his concept of "heterotopia", and Victor Turner's concept of "liminality" are introduced to discuss the convicts participating in a theatrical workshop as liminal individuals during the ritual of transition while in the heterotopian space of a prison.
\end{abstract}

Keywords: Shakespeare; Margaret Atwood; adaptation; classic; liminality; heterotopia; imprisonment.

\section{INTRODUCTION}

Margaret Atwood's sixteenth novel Hag-Seed was published in 2016 as part of the Hogarth Shakespeare project which commissioned various well-known authors of contemporary popular genres to re-imagine the classics of the British Bard into prose. The Hogarth Shakespeare project was first announced to the public in 2013 and concluded in 2018 after the publication of seven novels, all of which were adaptations of different Shakespearean plays. HagSeed is a retelling of Shakespeare's final play The Tempest, in which the story of Prospero, the rightful duke of Milan, betrayed by his brother and forced to live in isolation on a magical island, is transposed to the contemporary world.

ANNA JOANNA BARTNICKA, PhD student at the University of Wroclaw, Faculty of Letters, Institute of English Studies; e-mail: ajbartnicka@gmail.com; ORCID: 0000-0002-9252-499X. 
This paper analyses Atwood's novel as a metatextual adaptation of the literary classic. Commenting on her choice of The Tempest as a source material, Atwood expressed her view of the play as "in some ways, an early multimedia musical. If Shakespeare were working today he' $d$ be using every special effect technology now makes available" (Blurb). Using her characters as ventriloquist dummies, the author muses on the role of classical literature in modern world and the extent to which classics can be utilized by artists and layman readers alike. The motif of imprisonment, present in Shakespeare's original, is translated into a literal prison, which is the main place of action in the novel. Art, particularly in the form of classical texts, is shown as having universal educational value and being capable of transforming people's life and helping them to achieve freedom. The adaptation of The Tempest planned and performed by the characters of the novel is the encounter of real life and art, a moment of both punishment and reward, imprisonment and emancipation.

\section{ADAPTATION AND CLASSIC}

Fredric Jameson notices that even though many theorists have come up with different terms to describe the adaptive process, such as "translation", "incarnation" or "rewriting", what they all have in common is moving away from the "scarecrow of fidelity" (215). Rather than mirroring the original to the detail, adaptations are understood to create something entirely new. In turn, by being adapted and inviting further adaptations, original texts can turn into classics. There is, thus, a co-dependence between classics and adaptations. Hutcheon defines adaptations as "extended critical and creative engagements with a particular text" (39), which have a "double nature": they can be interpreted in isolation, as original texts, or in relation to their sources, as adaptations (6). Adapting is a dual operation because it always involves "(re-)interpretation" and "(re-)creation" (8), and only when the adaptation lacks enough creativity to signal the change of an author, it can be considered unsuccessful (20). Using the theory of evolution as a frame of reference, Hutcheon calls adaptations a form of migration in which a certain story moves to a different cultural and formal environment for the purpose of reproduction and survival (31-32). Adaptations seem to be beloved by the audiences, and Hutcheon indicates "repetition with variation" as the source of the special pleasure they evoke in their recipients (4). One of the key terms Hutcheon uses is "transcoding"switching from one medium or genre to another, changing the frame or context 
of the work, shifting its historical character into fictional or fictional into historical (7), changing the pacing of the story, its focalization, conclusion or "point of departure" (12). According to Hutcheon, an adaptation proves that it is possible to separate form from content (10); while changing the form, adaptations retain the original content of the adapted text: themes, characters, "units of story" (11).

Literary canon can be defined as a collection of classics, which are literary works remaining popular and valuable years after their creation (Mukherjee 43). A classic stays in a close relation to its own criticism (30), and what makes it capable of surviving is its universality and potential to be reinterpreted and reinvented (33). Adaptations may be seen as requiring and perpetuating a canon (Sanders 8). They can also expand it and reformulate it (8), because only through revisiting the tradition can we notice who has been excluded from it (10). In this sense, adaptation may be considered a "veritable marker of canonical status" (9).

Shakespeare's works have a particularly long history of rewrites. Not only were they brought "out of conventional highcultural theatre spaces" (Holland 41) and into "schools, colleges, and town halls" (27), and then back to the theaters, they were also significantly edited in order to match their changing audiences. Whether attempting to achieve a commercial success or keeping the plays away from the masses, it may seem that each new version of Shakespeare's works "negotiates concepts of high/low and popular/elite cultural formations" (28). Sanders suggests that what provides Shakespeare with the sort of readership that crosses cultural boundaries and generational differences is the similarity of his plays to the "communal, shared, transcultural, and transhistorical art forms of myth and fairy tale" (45). Additionally, some authors use Shakespeare as a means of validating their own works of art and inviting extended theoretical analysis, while others seek to call Shakespeare out for being an "embodiment of the conservative politics, imperialism, and patriarchism of a previous age" (46).

These various, often critical, approaches to the classic as a work of a literary ancestor, are what Harold Bloom refers to as "revisionary movements" (10), or "mechanisms of defense" (11), which for him are more psychological than formal in nature. Drawing on psychoanalysis and the Freudian "Oedipus complex", Bloom introduces the concept of "the anxiety of influence" which the newer authors, especially those "stronger", feel towards their predecessors while trying to achieve originality. For Bloom, "strong poets" do not idealize the works of their predecessors, but instead create new meaning through "misreading" and "distorting" them, consciously or not. They take 
part in a battle for "priority", which began in the Western literary tradition since the dawn of Renaissance and in which, according to the rules of nature, they are destined to fail (31). Interestingly, as Bloom indicates, Shakespeare himself makes an exception because he belongs to the age "before the anxiety of influence became central to poetic consciousness" (11).

The Tempest is not only a potent material for an abundance of adaptations, being one of the three most adapted works of Shakespeare (Sanders 52), but in itself it is metatheatrical and addresses the subject of adaptation and the power of theater in influencing reality. The wedding masque is not the sole performance within the play. In fact, most of the events taking place on the island are masterminded by Prospero and brought into reality by Ariel's powers, making them one big play within a play.

Gérard Genette provides the terminology for understanding Atwood's novel as highly "transtextual", or "palimpsestuous". A palimpsest, which is a text layered on top of a previous one, already fading, by using the same old parchment, is the metaphor employed by Genette to describe the process of forming a relationship between two works of literature in which one work is being communicated in the other. This relationship is called "transtextuality", or "textual transcendence", and it has five types, as distinguished by Genette: "intertextuality", "paratextuality", "metatextuality", "architextuality" and "hypertextuality" (1-5). Paratextuality is the connection of literary works through such elements outside of the core text as titles, subtitles, prefaces, blurbs or book covers (3). The title of Atwood's novel being a quote from the play and the brief summary of the play attached at the end of the book ("The Tempest: The Original") form a type of paratextuality. Furthermore, there are quotations from the play in the core text of the novel, which is what Genette defines as intertextuality. The critical commentary on the original play in the novel can be classified as metatextuality, and finally, the overall relationship between the novel and the play is that of hypertextuality. Hypertextuality is "any relationship uniting" a hypotext and a hypertext, the hypertext being "any text derived from a previous text [hypotext] either through ... transformation, or ... imitation" (7). The Tempest is thus a hypotext for which Hag-Seed functions as a hypertext.

Within Atwood's novel, there can be distinguished at least two adaptations of The Tempest: the modernized "interactive theater" version of the play being prepared and then performed by the prisoners, and Felix's life being played out parallel to that of Prospero's, both on a conscious and unconscious level_ "his Tempest of the headspace" (Atwood 37). Working with Anthony 
Price, the modern equivalent of Antonio, Felix gladly distanced himself from governmental representatives, board members and financial patrons, the relations with whom he always considered tedious and keeping him away from the actual "higher aims" (12). He intentionally separated real life from art, valuing experimental theater above anything else, which is what he is eventually being punished for when Tony usurps his position and replaces Felix. Unwilling to stay in the city, Felix drives away in his car feeling as if "blown by a high wind", bringing to mind Prospero's leaky boat on the sea (29). Calling himself Mr. Duke, a reference to Prospero's lost dukedom, Felix rents an old, dilapidated cottage where he lives in isolation, as if on a secluded island. During this social exile, Felix often links real life to the Shakespearean plays, as a way of entertaining himself, giving meaning to the new reality he inhabits and, most importantly, preventing himself from committing suicide.

After nine years of isolation, Felix is employed as a teacher at a correctional institute, where he prepares a program around the works of Shakespeare, particularly those which he guesses the convicts to understand and identify with. The novel proceeds to recapitulate how over the course of three years, Felix's methods of teaching bring positive results: "Astonishingly, their reading and writing scores went up, on average, by fifteen percent.... The effect was real" (54). During the fourth year of his new job, however, Felix's life once again drifts back to the plot of The Tempest, without his intention. It turns out that Felix's enemies, Anthony Price and Sal O'Nally, are going to attend Felix's performance as Ministers of Heritage and Justice, respectively, unaware of his true identity. In Felix's mind, they are "the politicos who ... have failed to grasp the redemptive power of art ... [and] think Shakespeare is a waste of time" (199), which is why they intend to cancel the literacy program at the prison.

The novel presents in detail the preparation of the performance, from the moment of casting the roles and negotiating the meaning with the actors, through searching for props and costumes, to the presentation of the final product. Felix's plan of revenge on Tony and Sal makes the performance "a play, within which there's another play", as Felix himself is aware (116). Even though there is a backstory for each of the convict characters, and they often voice opposing views, they seem to collectively have the same role: guiding the reader through the interpretative process, just like the brief summary of the original play at the end of the book. In one sense, the novel may be considered a guidebook to The Tempest, containing many facts about Shakespeare and many discussions on how his plays have changed throughout 
centuries. Since the characters adapting Shakespeare's play are prisoners without much experience in the field of arts and yet Felix, a great theatrical director, genuinely appreciates their contributions, it is a statement about the inclusiveness of the play-everyone is welcome to read it, interpret it and adapt.

Over the course of the novel, Felix almost blends into one with Prospero. Not only does he play Prospero's role in the prison adaptation and acts out Prospero's character in his real life, while preparing the revenge, he also uses Prospero as a means of communication and a way of understanding himself. When he wonders about the true identity of Prospero- "So many contradictions to Prospero! Entitled aristocrat, modest hermit? Wise old sage, revengeful old poop? Irritable and unreasonable, kindly and caring? Sadistic, forgiving? Too suspicious, too trusting?" - he is, in fact, trying to understand himself (179). Discussing Prospero's morality with the prisoners and questioning whether Prospero's actions in the play are justified, Felix is looking for the understanding of his own situation. When the prisoners agree with his interpretation of Prospero, he feels supported in his decision to punish Tony, even though the conversations never refer directly to him: "This time all hands go up. Felix unclenches his shoulders: relief" (130).

Not only is the novel itself an adaptation of The Tempest, Felix's life depicted in it is one as well, and finally, the prison performance is a separate adaptation too, which, interestingly enough, has two versions. The first of them is the actual performance-turned-riot (subsequently recorded as the evidence to threaten Tony with), the second: a pre-recorded version played to the warden, guards and other guests on "closed-circuit TVs", hacked into by one of the convicts, $8 \mathrm{Handz}$ (107). While the former brings real-life consequences, the latter's purpose is hiding the actual events inside the prison and creating the illusion of a parallel reality in which the Ministers have not been abducted and abused, allowing the performance to be enjoyed only as such. It is a statement, on Atwood's side, on the possibility of infinite multiplication of adaptations, like a Matryoshka doll, each with a different aim and a different level of connection to reality.

\section{FREEDOM AND IMPRISONMENT}

Prisons began replacing public torture as the dominant form of legal punishment only by the end of the eighteenth century, thus ending the longstanding tradition of the public "spectacle" in which the criminals were to be 
executed in front of an audience and the convicts to be humiliated in a theatrical fashion (Foucault, Discipline and Punish 8-9). The legal violence on the human body ceased to be an accepted punitive practice; instead, the body of a convict became an "instrument" by means of which his freedom could be suspended according to precise rules and for a specific period of time (11). Confined in a prison and under constant surveillance, the criminal was now divested of the most universal and valuable possession: his liberty. Punishment became a "hidden part of the penal system" and the act of inflicting it was stripped of its previous glory (9-10). Consequently, prison marked a change in morality, and penalty gained a new function of "transforming individuals" (233), whose all aspects of lives the prison became responsible for.

The most essential principle underlying the functionality of prisons is the "isolation of the convict from the external world", which was considered to have partly motivated his crime (236). Being locked in a cell and experiencing extended solitude was expected to allow the convict to reflect on his actions and feel remorseful about them (237). As a result of the emergence of prisons, the focus of the penal process was redirected from the crime to the criminal and his will as an individual (18). It shifted from affecting the convict's body to affecting his "soul" (16). It was no longer enough to punish the individual; he had to be transformed through constant supervision, and his habits and tendencies had to be altered using methods specifically tailored to the convict's individual character. The convict's stay in prison was not permitted to be interrupted and it had to last until the transformation was fully completed; there was a chance, however, for the punishment to be modulated in severity and length, as a form of reward for how well-behaved the prisoner became and how effectively he performed the tasks he was assigned. Work was, therefore, another essential aspect of prison life; it was expected to make the prisoners "docile", satisfying the need of their future utility outside of the prison (243).

One of the most noticeable changes in Atwood's adaptation of Shakespeare's The Tempest is the inclusion of an actual prison as the main location in the novel, as opposed to keeping the motif of imprisonment metaphorical. Punished with banishment for his negligence and artistic hubris, and treated almost like a criminal by his former colleagues, Felix Phillips assumes a new identity and leads a life of seclusion for nine years before being hired at the Fletcher County Correctional Institute. The prison becomes his island of choice, his place of isolation, reflection, work and transformation: "My island domain. My place of exile. My penance. My theatre" (Atwood 81). It is in the prison that Felix rediscovers theater, learning its utilitarian purpose and undergoing a transformation as an artistic director. 
The Correctional Institute is described in no uncertain terms as an unpleasant place to visit. Even though there is no "dungeon-like" appearance to it (78), many details imply its sensorily disagreeable nature, so characteristic of prisons as places of punishment: "Unfresh paint, faint mildew, unloved food eaten in boredom" (75), "cage-like ambience" (145), unwelcoming and discouraging from action. Everyone entering the prison is accompanied by the guards and inspected. From the outside, the prison is protected with the "chain-link fence, the barbed-wire topping, the searchlights" (145), effectively cut off from the rest of the world. The prisoners are located in blocks that correspond to the severity of their crimes. They have access to psychiatrists, chaplains, teachers and prisoners' rights advocates, who all exercise custody over the penal process, monitoring its different functions, as typical of modern prisons. One of the elective activities available to the convicts is the Literacy Through Literature workshop led by Felix. The "therapeutic and/or pedagogical efficacy" of the workshop is evaluated by the specialists on a higher level of power within the hierarchy of the prison system (79). These professionals perceive the convicts as "vulnerable men" who have experienced hardships in the past and need to be treated with care and responsibility. They are not "experimental mice" for Felix to make use of artistically (80), but individuals in need of cultural and educational guidance. The premise of the workshop is the belief that "the arts can be used as a therapeutic and educational tool" (71). Literacy is not the goal in itself, but rather a means of preparing the convicts to "find a meaningful place in the community once they're back in the world" (51). Felix has to "assert his authority" (54) for the purpose of teaching the convicts "more self-control" (41), but the workshop functions on the basis of teamwork and equal division of responsibility, with Felix only moderating the discussions and preparations. The prisoners use fictional names and Felix treats them like real actors. The educational aspect of staging a play at the workshop involves reading, discussing, planning, making decisions, working in groups and taking collective responsibility over the spectacles.

During one of the discussions with his convict actors, Felix formulates an impromptu definition of a prison: "any place or situation that you've been put in against your will, that you don't want to be in, and that you can't get out of" (122). Each prison, or "unique incarceration event" (122), has a defined prisoner and a jailer, as well as "enforcers" (130). Felix's loss of the position as the artistic director is a form of imprisonment, and his liberation depends on proving Tony's guilt. The aim of the prison riot thus becomes to create the circumstances in which Tony has no choice but to confess his crimes in front of an audience. It is an elaborate performance of revenge, reminiscent 
of the eighteenth century "judicial torture", rather than modern prisons such as the one in which the performance takes place. As described by Foucault (Discipline and Punish 39), "judicial torture" on the body of the criminal preceded prisons as places of Panopticon scrutiny over the prisoners. It was a "torture of truth" (40) which utilized "well-defined procedure[s]" of physical pain and public demonstration (40) as a means of extorting the confession out of the accused and simultaneously punishing him for the crime he committed (42). Even though Tony is not physically tortured per se, the reality of the situation influences him psychologically and emotionally, leading to the inevitable conclusion: a confession of guilt. Tony and Sal become Felix's prisoners, the convicts act as the enforcers of the penal process, and Felix is the invisible supervisor. For the duration of the performance, the penal system's hierarchy is temporarily reversed; the convicts, alongside Felix, gain control over the visitors from the ministry.

Felix is aware of the distress that is going to be inflicted not only on Tony, but also on the people accompanying him. It is Felix's intention for his enemies to be "[r]educed to a quivering jelly" (Atwood 131), and he even resorts to drugging his prisoners without their knowledge, leading them to a "druginduced anguish" (228). Arguably, the most heavily punished in the group is Sal, who experiences significant trauma when forced to believe that his son was murdered. Interestingly enough, for someone who has experienced the death of his own daughter, Felix has a very dismissive approach to Sal's suffering: “'I feel guilty about putting Lonnie through all this,' says Felix, 'but there's nothing to be done. Anyway, he's been keeping bad company"' (224). At times, the novel goes as far as to portray Sal's mental break-down humorously: "Sal is curled up in a corner of the room, clutching his knees. Tears are running down his cheeks; he's a diagram of woe. He seems to be having an interactive experience with the floor" (228).

During the ritual of torture and confession, Tony is made aware of the "crimes" he is charged with through the lyrics of a rap song, adding onto the multi-media, spectacle-like form of the revenge: "the beat floods the room. Caliban begins to chant", "But who's more monstrous than you?/You stole, you cheated, you bribed, you lied" (229-30). Tony is recorded plotting double murder for political gain, and rather than sharing the recording with the police, Felix uses it for blackmail. He presents his demands in exchange for keeping the information private: he is to regain his position as the art director, and the prison literacy program is to keep being funded by the government. Noticeably, there is no involvement of the actual justice system. 
For Felix, the performance is of a much higher value than any previous one, reaching an almost mystical quality after years of waiting and planning. It is a site of encounter between life and theater, with practical and aesthetic dimensions. For the duration of the play, Felix replaces the entire penal system, becoming the only guard of justice. He does not refrain from emotional engagement; the revenge brings him personal enjoyment, of which he is aware, in his mind portraying himself as a victim of injustices, fully deserving of reparation. The process of "torturing" his enemies seems even more important to Felix than its results. The punishment in the form of a theatrical play is Felix's way of presenting his regained power, a ritual of establishing his domination, a "ceremon[y] by which power is manifested" (Foucault, Discipline and Punish 47). Through executing his festive and glorious revenge, however, Felix seems to resemble the criminal whom he wishes to punish.

\section{HETEROTOPIA, LIMINALITY, SACRA}

According to Foucault, prisons belong to the category of heterotopia: a "counter-site" within the existing society, which has precisely defined functions reflective of that society, "represent[ing], contest[ing], and invert[ing]" it ("Of Other Spaces" 24). It is a place of otherness and simultaneous familiarity. It may juxtapose many real locations, thus becoming a "microcosm" symbolic of the "totality of the world" (26). One has to be forced or permitted to enter a heterotopia, which is not "freely accessible", and when inside, one has to break with the traditional passage of time (26). A more specific type of heterotopia: a heterotopia of deviation, such as prisons, contains "individuals whose behavior is deviant" according to the societal norms (25). It is an alternative way of ordering things which exists only in relation to the original: prisoners must abide by the rules which they have previously ignored in the outside world, only in their stricter and harsher form.

It is possible to perceive the prisoners in the Fletcher County Correctional Institute as well as Felix as being in a state of liminality, which is the middle phase in a ritual of transition, rite de passage, between the phases of separation and aggregation, also referred to as "separation", "transition", and "incorporation" (Gennep 11). A ritual of transition is a process of moving between the states, present in all types of societies but particularly characteristic of those "small-scale" (Turner, The Forest of Symbols 93). A "transitional-being", otherwise called a "liminal person", is a neophyte participating in a ritual, 
at the end of which he is to gain a new status or membership (95). In the liminal phase, the liminal person is characterized by "structural invisibility" and "ambiguity" (99), and lacks any proper identity within the social structures: "no longer classified and not yet classified" (96), "at once destructured and prestructured" (98). In this sense, liminality may be considered connected to heterotopia, both terms sharing the quality of ambiguity and otherness.

For the duration of the ritual of transition, a liminal being becomes part of a collective taught by instructors who employ sacra, which may be "evocatory instruments or sacred articles" (102), as well as instructions: the "revelation of the real", "mythical history" (103). The sacra are supposed to provoke the neophytes to think about the world and culture, therefore "[1]iminality may be partly described as a stage of reflection" (105). In his "Variations on a Theme of Liminality", Turner distinguishes between the "tribal-liminal" societies of the past and the industrial-liminoid societies of the modern industrial age (43). For the tribal societies, the rituals are considered part of work; the "communal participation" is obligatory and not optional, unlike the liminoid rituals in the modern society (39). However, this work can also be considered "play" (40), since the rituals are "[f]airs, fiestas, carnivals" and "games" (41). They are multisensory and employ acting roles and symbolism for the purpose of "discover[ing] something unknown" (40). Both liminal rituals and liminoid genres are characterized by reflexivity about the world surrounding their participants and involve parody as well as mockery. Such preindustrial liminal rituals are a way of creating spontaneous and temporary communitas, which are the opposite of social structura.

The small group of prisoners participating in the Shakespeare classes may seem closer to the tribal societies of the past than the modern "industrialliminoid" ones. Closed in the heterotopian space of a prison and therefore "invisible" or even "dead" to the rest of the society, they are in the process of transformation from criminals back to the law-abiding citizens of their country, having at the moment neither of these two identities. Turner refers to it as "a rite of passage of readmitting criminous and reprobate individuals ... into civil society" ("Variations on a Theme of Liminality" 46). Similarly to the convicts, Felix is a liminal person himself because his views on art and its purpose are in the process of transition, and art is the most crucial element of his identity. He learns that artistic work can be used for reaching common good, as opposed to being a creation of an individual's subjective desires.

The workshop, although voluntary, cannot be considered leisure time. It is rather part of the obligatory communal work. Accordingly, Shakespeare's texts act as sacra: under the supervision of Felix (the instructor), the convicts 
(liminal beings) are supposed to discuss the content of a given play (sacrum), analyze its symbolic meaning and relate it to the real-life context as well as the social norms outside of the prison, in preparation for the end of their sentences. Similarly, influenced by the convicts' opinions, Felix is taught how to approach art anew. Just like the tribal rituals, the performance of The Tempest prepared by Felix and the convicts employs all sensory modes: visual effects and costumes, music, text and physical acting. The complex process of performing as well as the preparation of it is expected to have a pedagogical effect upon the participants, allowing them to take collective decisions, leading them to discoveries, and finally, equipping them with useful knowledge to be employed in the future.

One could question, however, whether the prisoners participating in the performance actually meet the requirements of being considered "liminal beings" by the end of the novel. Their engagement in the performanceturned-riot seems to negate the transformative effect of the theatrical workshop and to keep them from entering the third stage of rite de passage, namely: incorporation. By helping Felix undergo his own transformation, they are, in fact, returning to their previous criminal identities, instead of gaining a new one.

\section{CONCLUSION}

Prospero's modern counterpart and the focalizer of Hag-Seed, Felix Phillips, is an artistic director whose perception of art is altered during years of social solitude and prison workshops. Starting off as a pompous and highly controversial creator of experimental performances that bear little relation to reality and which few viewers can understand, Felix uses The Tempest as a guidebook to find himself in the new reality once he loses his job and seeks revenge on his wrongdoers. By adapting Shakespearean plays with the convicts as his co-authors, he learns the utilitarian and communal role of art, bringing his adaptations closer to real life. The plays are not simply the source material for Felix's own idiosyncratic creations; they become sacra for educating liminal individuals in the heterotopia of a prison. The performances are rituals of transition which, as any kind of ritual, involve the usage of various sensory modes, and assume the form of multi-media interactive theater. The novel may be thus seen as the site of encounter and discussion between the classic and the adaptation, bringing together life and art, freedom and imprisonment. 


\title{
WORKS CITED
}

Atwood, Margaret. "A Perfect Storm: Margaret Atwood on Rewriting Shakespeare's Tempest." The Guardian, 24 Sept. 2016, www.theguardian.com/books/2016/sep/24/margaret-atwood-rewritingshakespeare-tempest-hagseed. Accessed 7 July 2020.

Atwood, Margaret. Hag-Seed. Penguin Random House, 2016.

Bloom, Harold. The Anxiety of Influence. A Theory of Poetry. 2nd ed., Oxford UP, 1997.

Foucault, Michel. Discipline and Punish. The Birth of the Prison. Translated by Alan Sheridan, Vintage Books, 1995.

Foucault, Michel, and Jay Miskowiec. "Of Other Spaces.” Diacritics, vol. 16, no. 1, 1986, pp. $22-27$.

Genette, Gérard. Palimpsests. Literature in the Second Degree. Translated by Channa Newsman and Claude Doubinsky, U of Nebraska P, 1997.

Gennep, Arnold van. The Rites of Passage. Translated by Monika B. Vizedom and Gabrielle L. Caffee, U of Chicago P, 1960.

Holland, Peter. "Shakespeare Abbreviated." The Cambridge Companion to Shakespeare and Popular Culture, edited by Robert Shaughnessy. Cambridge UP, 2007, pp. 26-45.

Hutcheon, Linda. A Theory of Adaptation. Routledge, 2006.

Jameson, Frederic. "Afterword: Adaptation as a Philosophical Problem." True to the Spirit: Film Adaptation and the Question of Fidelity, edited by Colin MacCabe et al., Oxford UP, 2011, pp. 215-233.

Mukherjee, Ankhi. What Is a Classic? Postcolonial Rewriting and Invention of the Canon. Stanford UP, 2014.

Sanders, Julie. Adaptation and Appropriation. Routledge, 2006.

Shakespeare, William. The Tempest. Wordsworth Editions Limited, 2004.

Turner, Victor. "Variations on a Theme of Liminality." Secular Ritual, edited by Sally F. Moore and Barbara G. Myerhoff, Van Gorcum, 1977, pp. 36-52.

Turner, Victor. The Forest of Symbols. Aspects of Ndembu Ritual. Cornell UP, 1967.

\author{
BURZA: CZARCI POMIOT MARGARET ATWOOD I DRAMATYCZNE SPOTKANIA \\ MIĘDZY KLASYKIEM I ADAPTACJĄ, ŻYCIEM I SZTUKĄ, WOLNOŚCIĄ I UWIĘZIENIEM
}

\author{
Streszczenie
}

Artykuł analizuje powieść Margaret Atwood Burza: Czarci Pomiot (2016) jako metatekstualną adaptację szekspirowskiego klasyka, Burzy. Pojęcia ,adaptacja” oraz „klasyk” są zdefiniowane w celu objaśnienia relacji między dziełem Atwood a jego materiałem źródłowym. Adaptacja Burzy przygotowana przez bohaterów powieści, w której angażują się więźniowie, jest formą multimedialnego, interaktywnego teatru, a szekspirowski klasyk jest rodzajem „sacra” (Turner) o wartościach edukacyjnych i utylitarnych. Analiza historii więziennictwa Michela Foucault, oraz jego koncept „heterotopii”, a także koncept „liminalności” według Victora Turnera, są przywołane w celu analizy więźniów uczestniczących w warsztatach teatralnych jako jednostek liminalnych w rytuale przejścia w heterotopijnej przestrzeni więzienia.

Słowa kluczowe: Szekspir; Margaret Atwood; adaptacja; klasyk; liminalność; heterotopia; uwięzienie. 